\title{
Convolutional Neural Network Untuk Metode Klasifikasi Multi-Label Pada Motif Batik \\ Convolutional Neural Network for Multi-Label Batik Pattern Classification Method
}

\author{
Taufiqotul Bariyah ${ }^{1}$, Mohammad Arif Rasyidi ${ }^{2}$, Ngatini $^{3}$ \\ 1,2,3 Informatika, Universitas Internasional Semen Indonesia \\ E-mail: ${ }^{1}$ taufiqotul.bariyah@uisi.ac.id, ${ }^{2}$ mohammad.rasyidi@ uisi.ac.id, ${ }^{3}$ ngatini @uisi.ac.id
}

\begin{abstract}
Abstrak
Salah satu warisan budaya Indonesia yang diakui dunia adalah kain batik. Beragamnya motif batik di Indonesia membuat masyarakat awam sulit membedakan motif-motif yang ada. Penelitian terkait klasifikasi dan pengenalan motif batik saat ini kebanyakan berfokus pada klasifikasi satu jenis motif batik (single-label) yang terdapat pada suatu citra. Padahal, beberapa kain batik yang ada memiliki lebih dari satu motif sebagai penyusunnya. Penelitian ini bertujuan untuk melakukan klasifikasi multi-label citra motif batik dengan menggunakan convolutional neural network (CNN). CNN merupakan salah satu algoritma deep learning pengembangan multi-layer perceptron (MLP) yang telah banyak digunakan dalam klasifikasi data, khususnya klasifikasi citra. Hasil penelitian ini menunjukkan akurasi penggunaan arsitektur CNN dalam melakukan klasifikasi multi-label pada 15 motif batik mencapai $91.41 \%$ dari 300 citra uji dengan menggunakan epoch 100.
\end{abstract}

Kata kunci: klasifikasi multi-label, convolutional neural network, pengolahan citra, motif batik

\begin{abstract}
Batik is one of Indonesia's cultural heritages that has been recognized worldwide. The variety of batik motifs in Indonesia makes it difficult for ordinary people to distinguish between existing motifs. Research related to the classification and recognition of batik motifs is currently based mostly on the classification of one type of batik motif found in an image or known as single label classification. In fact, some existing batik fabrics have more than one motif. This study aims to perform a multi-label classification of batik motif images using a convolutional neural network $(C N N) . C N N$ is one of the deep learning algorithms which is a multi-layer perceptron (MLP) development and has been widely used in data classification, especially image classification. The results showed the accuracy of using CNN architecture in multi-label classification on 15 batik motifs reach $91.41 \%$ of the 300 test images using epoch 100.
\end{abstract}

Keywords: multi-label classification, convolutional neural network, image processing, batik motif

\section{PENDAHULUAN}

Sebagai warisan budaya yang telah diakui dunia, batik menjadi salah satu corak mode yang banyak dipakai oleh masyarakat. Keberagaman motif batik yang ada saat ini tak luput dari penggunaan batik sebagai busana sehari-hari. Jika sebelumnya batik dikenal sebagai pakaian yang hanya bisa digunakan untuk menghadiri acara formal, maka saat ini batik bisa digunakan sebagai pakaian harian. Kombinasi corak atau motif batik maupun model pakaian batik juga telah disesuaikan dengan perkembangan zaman sehingga dapat menunjang penampilan.

Asal kata 'Batik' adalah dari kata Bahasa Jawa 'amba' dan kata 'nitik' yang berarti melempar titik berkali-kali pada kain yang lebar [1]. Sebagai kain tradisional, batik dibuat dengan menggunakan bantuan tangan secara manual wax-resist dyeing technique [2,3]. Motif atau corak pada kain batik dapat digolongkan menjadi dua, yaitu motif batik geometris dan motif batik nongeometris. Motif batik geometris adalah motif batik yang tersusun dari corak geometris, seperti kawung, ceplok, dan banji. Motif batik non-geometris adalah motif batik yang tersusun dari corak 
non-geometris, seperti corak tumbuhan, hewan, atau corak candi [4]. Gambar 1 menunjukkan contoh motif batik geometris dan motif batik non-geometris [3]. Setiap daerah memiliki corak yang beragam dan berbeda dengan kekhasannya masing-masing. Disamping karena perbedaan daerah asal batik, teknik pembuatan batik turut serta dalam menyumbang keanekaragaman motif batik yang ada. Masing-masing motif batik memiliki filosofi penciptaan dan nilai sejarahnya sendiri [5]. Hal ini menambah ketertarikan masyarakat atas beragam jenis motif yang ada.

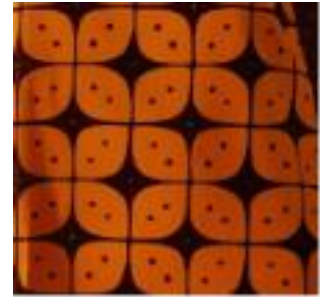

Geometris

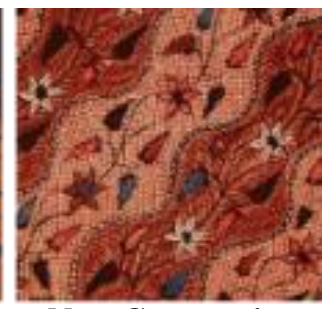

Non-Geometris

Gambar 1 Corak batik geometris dan non-geometris

Tidak hanya di Indonesia, ketertarikan akan batik juga merambah dunia internasional. Banyak wisatawan mancanegara yang datang ke Indonesia dan sering menjadikan batik sebagai salah satu buah tangan wajib untuk dibawa ke negara asalnya. Informasi tentang ragam jenis batik yang ada juga turut dicari oleh masyarakat. Meskipun telah ada upaya untuk mengumpulkan data dan informasi tentang motif batik di Indonesia, tetapi beragamnya corak yang ada membuat sebagian besar masyarakat awam merasa kesulitan dalam membedaan motif-motif yang ada. Keunikan dan daya tarik dari batik berasal dari motif yang diberikan, namun kebanyakan masyarakat tidak mengetahui tentang beragamnya jenis motif batik tersebut [6]. Beberapa kain batik yang ada juga tersusun atas beberapa motif yang berbeda. Sebagai bentuk pelestarian terhadap kekayaan budaya di Indonesia, sangat penting untuk dilakukannya penelitian yang berkaitan dengan pengembangan batik itu sendiri. Salah satu upaya untuk melakukan pengenalan dan klasifikasi motif batik dapat dilakukan adalah dengan membangun sebuah sistem berbasis kecerdasan buatan yang mampu mengenali motif batik yang ada sehingga dapat memberikan informasi terkait motif batik tersebut.

Penggunaan kecerdasan buatan khususnya dalam klasifikasi dan pengenalan citra batik telah banyak dikembangkan. Pada penelitian yang telah dilakukan sebelumnya, Fuad dan Suciyati menggunakan Boosted Random Fern untuk melakukan klasifikasi multi-label motif batik dan mampu mendeteksi 62 citra testing dengan benar dari total 64 citra [7]. Rangkuti menggunakan metode Fuzzy Neural Network (FNN) yang dikombinasikan dengan wavelet transform untuk mengklasifikasikan motif batik dan menghasilkan model dengan akurasi sebesar 86-92\% [8]. Klasifikasi motif batik juga dilakukan oleh Haryono, dkk dengan menggunakan momen invariant, eccentricity, dan compactness untuk mengklasifikasikan motif batik dengan metode $K$-Nearest Neighbours [9]. Dari hasil penelitian tersebut diperoleh bahwa fitur momen invariant memiliki hasil akurasi yang lebih baik dibandingkan dengan fitur eccentricity maupun compactness. Dalam penelitian lain, Kasim, dkk menggunakan jaringan syaraf tiruan dan Gray Level Co-occurrence Matrices (GLCM) untuk mengklasifikasikan citra batik [10]. Hasil akhir yang diperoleh dari klasifikasi citra batik tersebut yaitu, shape feature memiliki tingkat akurasi terendah 80,95 \%, dan kombinasi texture and shape features menghasilkan nilai akurasi yang lebih besar sebesar 90,48\%. Dalam penelitian-penelitian tersebut menunjukkan bahwa terdapat peningkatan keakuratan klasifikasi citra batik menggunakan jaringan syaraf tiruan dengan kombinasi fitur tekstur dan bentuk pada citra batik. Meskipun hasilnya terlihat cukup menjanjikan, studi-studi tersebut menggunakan jumlah data citra yang sangat terbatas serta kebanyakan digunakan untuk klasifikasi dan pengenalan citra batik yang terdiri dari satu motif batik saja.

Pada penelitian ini akan dilakukan klasifikasi multi-label pada citra batik yang memiliki lebih dari satu motif batik. Klasifikasi multi-label akan melabeli setiap sampel dengan label $m$ dari $n \_$classes kemungkinan kelas, di mana $m$ dapat berupa 0 hingga $n \_c l a s s e s$ inklusif. Sehingga 
dapat dianggap sebagai memprediksi sifat/property sampel yang tidak saling eksklusif [11]. Dalam klasifikasi multi-label, setiap sampel bisa dikaitkan dengan satu set label kelas [12]. Penelitian ini menggunakan model Convolutional Neural Network (CNN) sebagai arsitektur model klasifikasi citra multi-label pada motif batik.

$\mathrm{CNN}$ termasuk salah satu algoritma deep learning yang merupakan pengembangan dari multi-layer perceptron (MLP), sehingga CNN dapat digunakan untuk melakukan klasifikasi data yang berlabel [13]. Namun, berbeda dari MLP yang merepresentasikan neuronnya dalam satu dimensi, CNN merepresentasikan neuronnya dalam bentuk dua dimensi [14]. CNN merupakan salah satu model yang populer dan akurat untuk diimplementasikan dalam klasifikasi citra. Beberapa penelitian sebelumnya telah banyak mengimplementasikan CNN untuk melakukan klasifikasi citra, seperti klasifikasi citra makanan tradisional [15], klasifikasi citra tumbuhan [16, 17], klasifikasi citra hewan [14, 18], klasifikasi citra aksara Jawa [19, 20], serta pengenalan objek dan karakter pada plat nomor kendaraan [21-24] dengan performa yang sangat baik.

Berdasarkan latar belakang masalah serta hasil dari penelitian-penelitian di atas, maka pada penelitian ini CNN dipilih sebagi model yang akan digunakan untuk melakukan klasifikasi multi-label citra batik, yaitu klasifikasi motif yang terdapat pada kain batik yang tersusun dari beberapa motif yang berbeda.

\section{METODE PENELITIAN}

Dataset yang digunakan pada penelitian ini merupakan dataset citra batik yang dikumpulkan dari berbagai sumber, seperti toko luring dan pengrajin batik, serta dari toko daring maupun mesin pencarian daring. Dataset yang dikumpulkan kemudian diubah menjadi citra dalam format jpg. Dalam penelitian ini digunakan 15 motif citra yang berbeda sebagai label prediksi motif batik, yaitu motif batik Banji, Buketan, Ceplok, Encim, Kawung, Lung-lungan, Madura, Mega Mendung, Parang Rusak, Parang, Sekar Jagad, Truntum, Kipas, Semen, dan Fauna. Contoh citra jenis motif batik yang digunakan dalam penelitian ini dapat dilihat pada Gambar 2. Tahap metode penelitian yang dilakukan terdiri dari pengumpulan data citra, preprocessing data citra, pembangunan model CNN, dan pengujian model. Gambar 3 merupakan ilustrasi tahapan penelitian yang dilakukan.

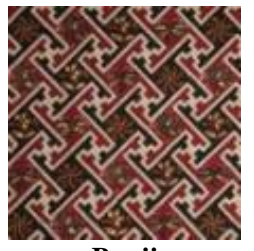

Banji

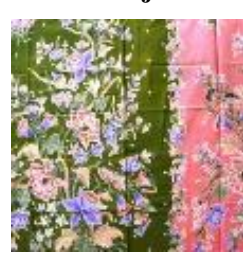

Buketan

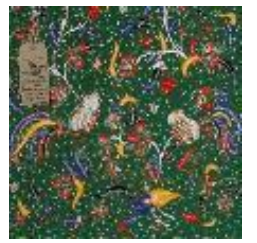

Madura

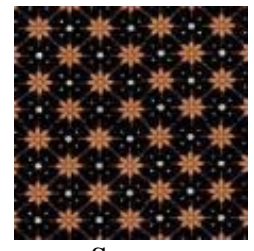

Semen

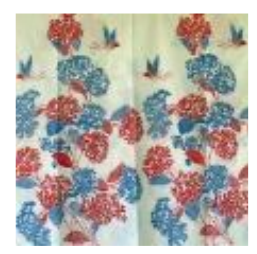

Encim

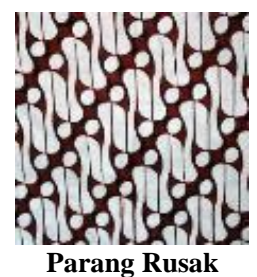

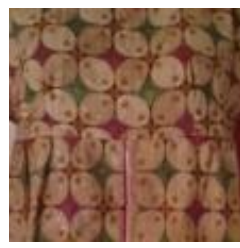

Kawung

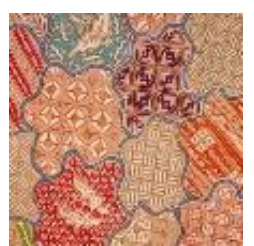

Sekar Jagad

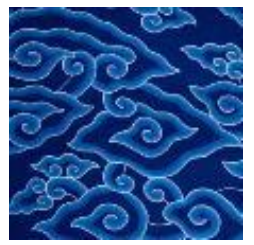

Mega Mendung

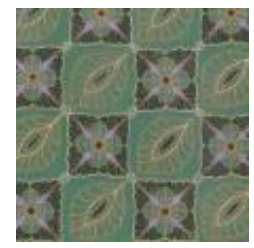

Ceplok

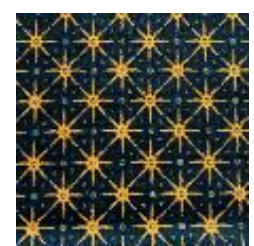

Truntum

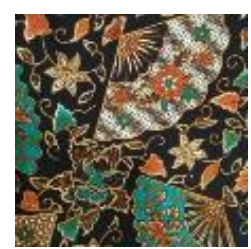

Kipas

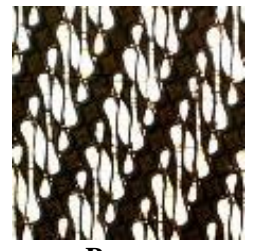

Parang

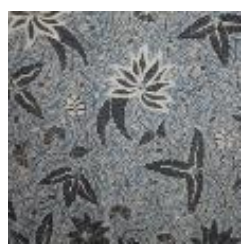

Lung-lungan

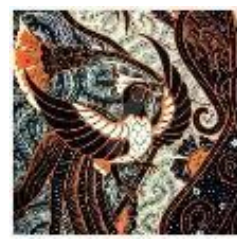

Fauna

Gambar 2 Motif batik yang digunakan dalam penelitian 


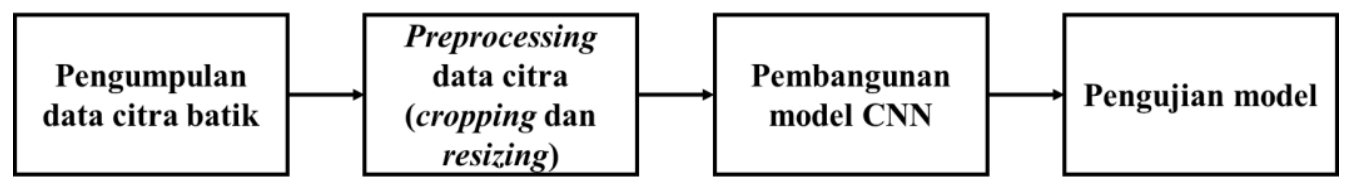

Gambar 3 Alur metodologi penelitian

\subsection{Pengumpulan Data}

Tahap pertama yang dilakukan adalah mengumpulkan dataset citra batik yang akan digunakan dalam penelitian ini. Terdapat 3000 data citra batik yang akan digunakan dalam penelitian ini. Dataset citra ini didapatkan dari pencarian daring, toko daring, toko luring, maupun pengrajin batik setempat. Dataset yang telah dikumpulkan selanjutnya akan dibagi menjadi dua bagian, yaitu dataset training dan dataset testing. Dalam penelitian ini digunakan perbandingan 90\% (2700 citra) dataset training dan 10\% (300 citra) untuk dataset testing.

\subsection{Preprocessing Data Citra}

Setelah tahap pengumpulan dataset selesai dilakukan, selanjutnya adalah melakukan tahap preprocessing terhadap citra di dataset. Preprocessing ini dilakukan untuk semua dataset, baik dataset training maupun dataset testing. Tahap preprocessing citra ini meliputi cropping (pemotongan citra) dan resizing (pengubahan ukuran) citra menjadi berukuran 350x350 piksel. Hal ini dilakukan karena perbedaan ukuran citra yang terdapat dalam dataset. Tabel 1 merupakan ilustrasi tahap preprocessing yang dilakukan pada citra dataset.

Tabel 1 Hasil implementasi tahap preprocessing citra dataset

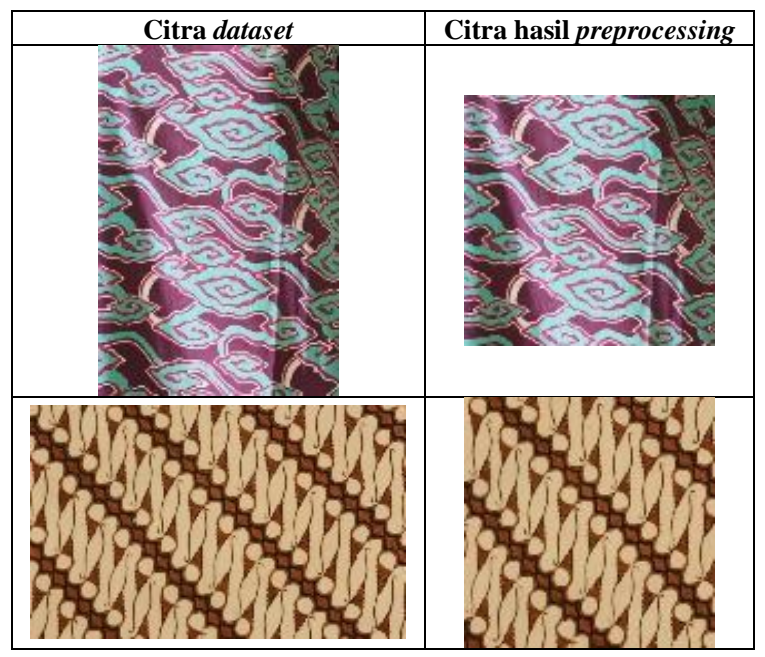

\subsection{Pembangunan Model CNN}

Tahap ketiga adalah tahap pembangunan model CNN. Pembangunan model CNN ini akan menggunakan data training yang telah disiapkan sebelumnya dan telah melalui tahap preprocessing. Pada tahapan ini, pembangunan model CNN dilakukan dengan menggunakan bahasa pemrograman Python dan library Keras. Model CNN dibangun dengan menggunakan dasar model CNN yang telah dibangun oleh peneliti-peneliti sebelumnya.

Pada tahap pembangunan model CNN ini, akan ditentukan pula arsitektur model yang dibangun, seperti jumlah hidden layer (lapisan tersembunyi) yang digunakan, jumlah neuron (saraf) pada setiap layer, maupun fungsi aktivasi yang digunakan. Setelah model CNN dibangun, perlu dilakukan proses learning (pembelajaran) yang dilakukan oleh model CNN tersebut terhadap dataset training. Pada proses training ini, model CNN yang dibangun akan belajar untuk mengenali citra motif batik dari dataset training dengan label motif yang sesuai dan 
berkorespondensi dengan citra motif batik tersebut. CNN merupakan salah satu algoritma deep learning yang cukup banyak digunakan karena CNN mampu melakukan ekstraksi fitur secara otomatis. Hal ini dapat dilakukan oleh CNN karena CNN dapat melakukan pembelajaran secara mandiri untuk mencari representasi objek berdasarkan data yang diberikan. Ekstraksi fitur dalam model CNN dilakukan secara otomatis pada tahap convolution, yang terdiri dari convolutional layer dan pooling layer.

Sebagaimana jaringan saraf lainnya, CNN terdiri dari neuron (saraf) yang memiliki weight dan activation function. CNN bekerja dengan menggerakan sebuah kernel konvolusi (filter) berukuran tertentu ke sebuah citra agar didapatkan informasi representatif baru dari hasil perkalian bagian citra tersebut dengan filter yang digunakan. CNN diawali dengan memecah citra menjadi citra baru yang berukuran lebih kecil dan saling tumpeng tindih. Selanjutnya masingmasing citra kecil tersebut akan dimasukkan dalam jaringan saraf kecil (small neural network) yang hasilnya akan disimpan dalam sebuah array baru, proses ini disebut sebagai konvolusi (convolution). Selanjutnya akan dilakukan downsampling atau max pooling untuk mengambil nilai pixel terbesar dalam setiap pooling kernel. Langkah terakhir adalah melakukan prediksi terhadap citra tersebut berdasarkan jaringan saraf yang telah terkoneksi secara utuh atau biasa disebut sebagai fully connected layer. Langkah kerja CNN ini dapat dilihat dalam Gambar 4.

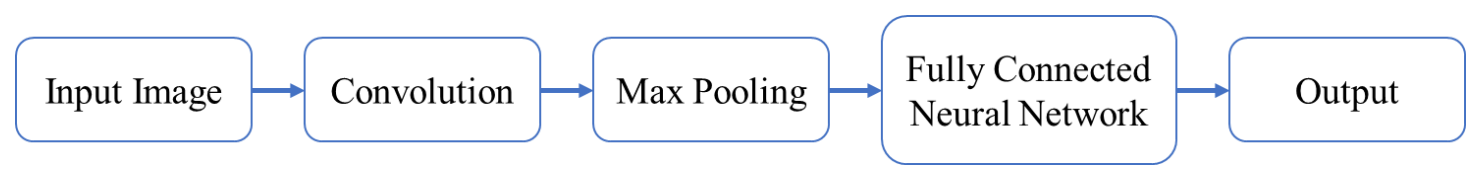

Gambar 4 Cara kerja CNN

Klasifikasi multi-label merupakan sebuah permasalahan klasifikasi citra yang unik. Permasalahan klasifikasi multi-label sendiri berbeda dari klasifikasi multi-kelas. Ketika hanya terdapat dua kelas yang digunakan untuk melakukan klasifikasi citra, maka permasalahan ini dinamakan sebagai permasalahan klasifikasi citra biner. Pada ilustrasi klasifikasi citra biner yang ditunjukkan Gambar 5, terlihat bahwa citra akan diklasifikasikan dalam dua kelas, anjing atau bukan anjing.

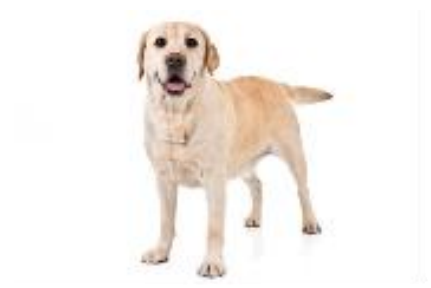

(a)

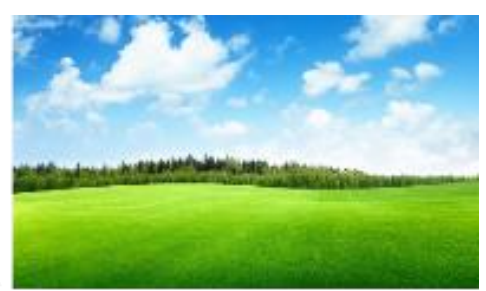

(b)

Gambar 5 Klasifikasi citra biner anjing vs bukan anjing

Ketika sebuah citra dapat diklasifikasikan dalam satu atau lebih kelas, maka permasalahan ini dapat disebut sebagai permasalah klasifikasi multi-label. Perbedaan mendasar dari klasifikasi multi-label dan klasifikasi multi-kelas adalah ketika terdapat lebih dari dua kategori yang dapat diklasifikasikan dalam sebuah citra dan citra tersebut tidak termasuk dalam lebih dari satu kategori, maka permasalahan ini dapat disebut sebagai permasalahan klasifikasi citra multi-kelas sebagaimana ilustrasi pada Gambar 6. Terlihat dalam Gambar 6 bahwa citra akan diklasifikasikan dalam empat jenis hewan yang berbeda, dimana setiap citra hanya terdiri dari satu objek yang masuk dalam satu jenis hewan saja. Apabila citra yang diklasifikasikan tersebut termasuk dalam lebih dari satu kelas, maka permasalahan ini dapat disebut sebagai permasalahan klasifikasi multi-label sebagaimana yang diilustrasikan oleh Gambar 7. Pada Gambar 7 terlihat bahwa citra yang akan diklasifikasikan mempunyai dua objek atau lebih yang dapat masuk dalam beberapa jenis hewan. 


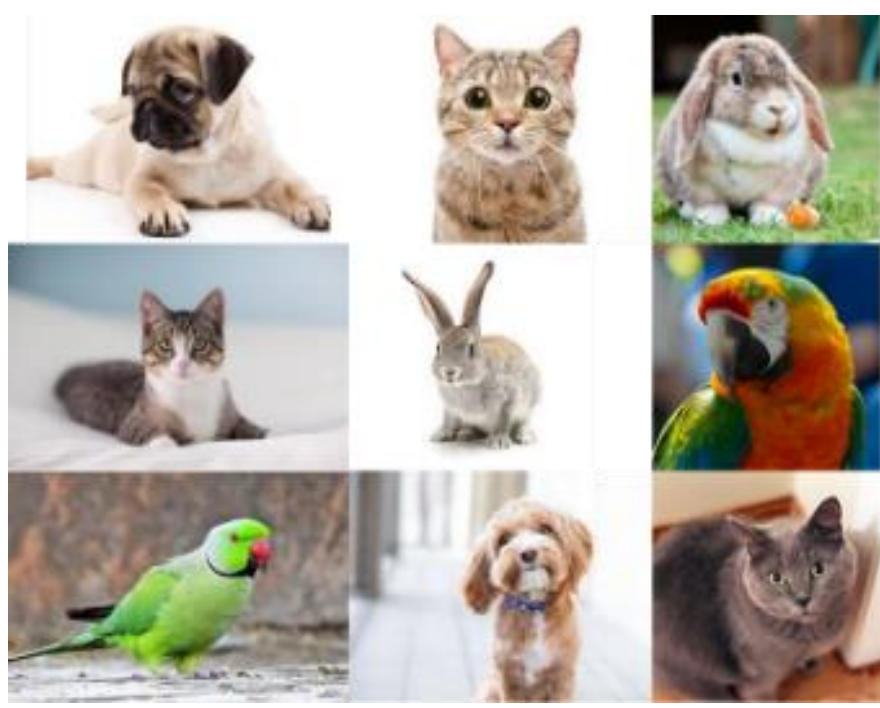

Gambar 6 Ilustrasi permasalahan klasifikasi multi-kelas

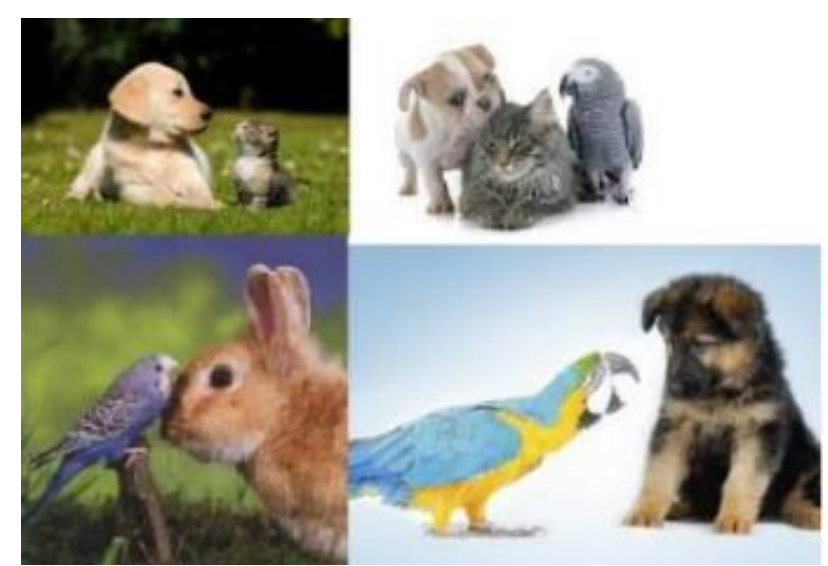

Gambar 7 Ilustrasi permasalahan klasifikasi multi-label

Pada klasifikasi citra multi-label, sebuah citra dapat memiliki lebih dari satu label. Sehingga probabilitasnya tidak tergantung satu dengan yang lainnya. Jika fungsi softmax digunakan sebagai activator, maka hasilnya akan menjadi kurang sesuai karena fungsi softmax akan membuat probabilitas setiap label menjadi bergantung pada label lainnya. Sehingga, dalam model CNN yang dibangun pada penelitian ini digunakan fungsi sigmoid sebagai activator. Pendekatan pemecahan permasalahan klasifikasi multi-label yang digunakan dalam penelitian ini adalah dengan mengubahnya menjadi permasalahan klasifikasi n-binary. Sehingga untuk setiap citra akan didapatkan probabilitas yang menyatakan apakah citra tersebut termasuk kelas 1 atau bukan, dan seterusnya.

\subsection{Pengujian Model}

Tahap terakhir yang dilakukan dalam penelitian ini adalah melakukan pengujian model $\mathrm{CN}$ yang telah dibuat dengan memakai dataset testing. Penelitian ini berfokus pada pengujian data loss dan accuracy. Tetapi sebagai perbandingan, pengujian untuk hasil recall, precision, dan F-measure juga dilakukan.

Data loss biasa digunakan untuk memaksimalkan kinerja algoritma machine learning dan didasarkan pada seberapa baik kinerja model yang dibuat dalam tahap training dan validasi model. Data loss dapat mengindikasikan seberapa buruk atau seberapa baik suatu model setelah dilakukan iterasi pengoptimalan model. Accuracy biasa digunakan untuk mengukur kinerja 
algoritma yang dibuat. Accuracy merupakan rasio prediksi benar keseluruhan data. Recall atau sensitivitas adalah proporsi prediksi benar positif dibandingkan dengan keseluruhan data yang benar positif. Precision adalah proporsi prediksi benar positif dibandingkan dengan keseluruhan hasil yang diprediksi positif. Sedangkan $F$-measure adalah perbandingan rata-rata precision dan recall yang dijumlahkan.

Pada klasifikasi tradisional seperti permasalahan klasifikasi multi-kelas, akurasi merupakan kriteria evaluasi yang umum digunakan. Selain itu, metrik evaluasi seperti precision, recall, maupun f-measure merupakan metrik evaluasi yang biasa digunakan untuk masalah klasifikasi multi-kelas label tunggal (single-label multi-class classification problems) yang berbeda dengan permasalahan klasifikasi multi-label [25]. Dalam klasifikasi multi-label, prediksi untuk sebuah contoh data adalah sekumpulan label, sehingga prediksi yang didapatkan bisa sepenuhnya benar (fully correct), sebagian benar (partially correct) dengan tingkat ketepatan yang berbeda, atau sepenuhnya salah (fully incorrect). Sedangkan metrik-metrik evaluasi yang ada tidak satupun yang menangkap gagasan tersebut dalam bentuk aslinya. Sehingga metrik evaluasi untuk permasalahan klasifikasi multi-label dapat dibedakan menjadi tiga kelompok, yaitu: mengevaluasi partisi (evaluating partition), mengevaluasi peringkat (evaluating ranking), dan menggunakan hierarki label [26]. Dalam penelitian ini akan digunakan model metrik evaluasi dengan menggunakan evaluating partition terhadap label yang ada.

Untuk mengatasi klasifikasi multi-label yang mengakomodasi hasil sebagian benar (partially correctness), Godbole dan Sarawagi mengusulkan definisi yang berbeda dari persamaan asal terkait metrik evaluasi yang ada [27].

Misalkan:

$T$ adalah dataset multi-label yang terdiri dari $n$ contoh multi-label $\left(x_{i}, Y\right), 1 \leq i \leq n,\left(x_{i} \in X, Y_{i} \in Y\right.$ $\left.=\{0,1\}^{k}\right)$,

$L$ adalah sekumpulan label, $|L|=k$, $h$ adalah pengklasifikasi (classifier) multi-label, dan $Z_{i}=h\left(x_{i}\right)=\{0,1\}^{k}$ adalah himpunan keanggotaan label yang diprediksi oleh $h$ untuk contoh $x_{i}$.

Maka, accuracy untuk setiap instance didefinisikan sebagai proporsi label yang diprediksi benar dengan jumlah total (prediksi dan aktual) label untuk instance tersebut. Accuracy keseluruhan adalah rata-rata di semua instance. Nilai accuracy dapat dihitung menggunakan Persamaan 1.

$$
\text { Accuracy, } A=\frac{1}{n} \sum_{i=1}^{n} \frac{\left|Y_{i} \cap Z_{i}\right|}{\left|Y_{i} \cup Z_{i}\right|}
$$

Precision adalah proporsi prediksi label yang benar dengan jumlah total label sebenarnya, dirata-ratakan dari semua instance. Nilai precision dapat dihitung dengan Persamaan 2.

$$
\text { Precision, } P=\frac{1}{n} \sum_{i=1}^{n} \frac{\left|Y_{i} \cap Z_{i}\right|}{\left|Z_{i}\right|}
$$

Recall adalah proporsi label yang diprediksi benar dengan jumlah total label yang diprediksi, dirata-ratakan dari semua instance. Nilai recall dapat dihitung dengan Persamaan 3.

$$
\text { Recall, } R=\frac{1}{n} \sum_{i=1}^{n} \frac{\left|Y_{i} \cap Z_{i}\right|}{\left|Y_{i}\right|}
$$

F-Measure merupakan rata-rata precision dan recall harmonik). Nilai f-measure dapat dihitung dengan Persamaan 4.

$$
F-\text { Measure, } F_{1}=\frac{1}{n} \sum_{i=1}^{n} \frac{2\left|Y_{i} \cap Z_{i}\right|}{\left|Y_{i}\right|}+\left|Z_{i}\right|
$$

Sebagaimana pada klasifikasi multi-class dengan label tunggal, semakin tinggi nilai accuracy, precision, recall dan f-measure maka semakin baik pula performa algoritma pembelajaran tersebut.

\section{HASIL DAN PEMBAHASAN}

Penelitian ini menggunakan model CNN dalam menentukan klasifikasi multi-label citra batik untuk 15 motif batik, yaitu motif Banji, Buketan, Ceplok, Encim, Kawung, Lung-lungan, Madura, Mega Mendung, Parang Rusak, Parang, Sekar Jagad, Truntum, Kipas, Semen, dan Fauna. Data citra yang digunakan dalam penelitian ini berjumlah 3000 citra dataset yang dibagi 
menjadi 2700 citra data training dan 300 citra data testing. Tahap selanjutnya adalah melakukan prepocessing pada data training dan data testing, yaitu dengan melakukan cropping dan resizing. Setelah tahap preprocessing selesai dilakukan, tahap selanjutnya adalah membangun model CNN yang akan digunakan untuk melakukan klasifikasi multi-label terhadap citra motif batik yang telah disiapkan sebelumnya. Pembangunan model CNN pada penelitian ini menggunakan bahasa pemrograman Python dan library Keras. Arsitektur model CNN yang dibangun dalam penelitian ini menggunakan sigmoid sebagai activator dan Adam sebagai fungsi optimizer, selain itu digunakan pula fungsi binary cross entropy untuk mengurangi data loss.

Setelah model CNN selesai dibangun, selanjutnya dilakukan pengujian dengan cara menerapkan model yang telah dibangun tersebut terhadap 300 data testing yang telah disiapkan. Selanjutnya dilakukan perhitungan accuracy, recall, precision, dan f-measure menggunakan Persamaan 1-4. Hasil pengujian didapatkan nilai accuracy terhadap model CNN yang dibangun dengan epoch 100 sebesar $91.41 \%$, loss sebesar $0.344 \%$, recall sebesar $86.96 \%$, precision sebesar $94,5 \%$, dan f-measure sebesar $90.5 \%$. Nilai accuracy yang mendekati angka $100 \%$ memiliki makna semakin baik performa model tersebut dalam melakukan pencocokan citra. Contoh hasil prediksi klasifikasi multi-label pada citra batik dapat dilihat pada Tabel 2.

Tabel 2 Hasil pengujian model CNN

\begin{tabular}{|c|c|c|c|}
\hline Nama Citra & Citra Batik & Motif Aktual & Motif Prediksi \\
\hline B0001.jpg & & Banji, Fauna & Banji, Fauna \\
\hline B0002.jpg & & Parang, Kawung, Buketan & Ceplok, Kawung, Buketan \\
\hline B0003.jpg & & Sekar Jagad, Truntum & Sekar Jagad, Buketan \\
\hline B0004.jpg & & Parang, Kipas & Parang, Kipas \\
\hline B0005.jpg & & Ceplok, Parang & Ceplok, Parang \\
\hline
\end{tabular}

Sebagaimana yang terlihat dalam grafik pada Gambar 8, nilai accuracy pada model yang dibangun cenderung meningkat. Nilai accuracy tertinggi terjadi pada epoch ke-92. Sebaliknya, nilai loss menurun sampai pada nilai terendah di epoch ke-78 dan kembali meningkat pada epoch ke-79. Hal ini mungkin terjadi karena sebagaimana umumnya algoritma machine learning, 
kecepatan pembelajaran (learning rates) yang rendah akan menyebabkan peningkatan data loss secara linear. Ketika kecepatan pembelajaran meningkat, maka data loss yang dihasilkan juga akan menurun, sampai pada akhirnya akan terjebak pada nilai loss yang mungkin lebih jelek.

Klasifikasi multi-label merupakan sebuah permasalahan yang unik, karena permasalahan ini merupakan permasalahan yang berbeda dari klasifikasi single-label. Pada klasifikasi multi-label, sangat mungkin terjadi kasus overfitting. Hal ini bisa terjadi apabila terdapat ketidakseimbangan data dalam klasifikasi multi-label. Ketidakseimbangan data sendiri telah menjadi masalah yang cukup umum dalam machine learning, dimana beberapa kelas dalam dataset lebih sering muncul daripada yang lainnya, sedangkan jaringan saraf (neuron) hanya belajar untuk memprediksi kelas yang paling sering muncul [28]. Beberapa teknik yang dapat digunakan untuk mengatasi ketidakseimbangan data adalah dengan melakukan downsampling atau upsampling, serta penggunaan metode ensemble machine learning (EML) [29].

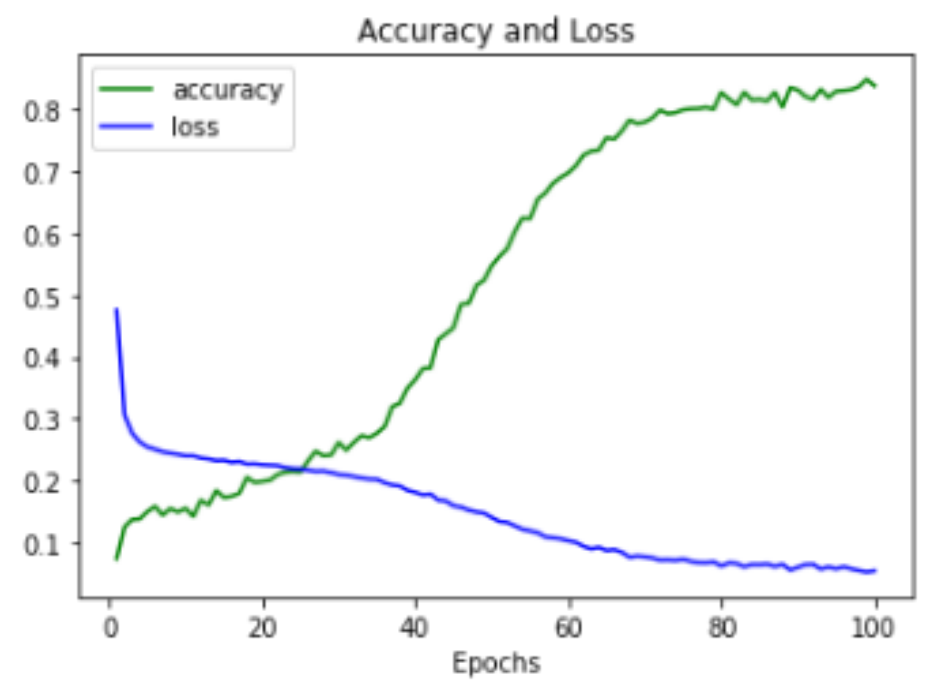

Gambar 8 Nilai accuracy dan data loss model CNN yang dibangun

\section{KESIMPULAN DAN SARAN}

Pengklasifikasian motif batik Indonesia yang beragam dapat dilakukan dengan menggunakan bantuan kecerdasan buatan. Pada penelitian ini, convolutional neural network (CNN) digunakan untuk melakukan klasifikasi multi-label pada citra kain batik yang memiliki motif lebih dari satu. Pengujian pada model CNN yang dibangun menghasilkan nilai accuracy sebesar $91.41 \%$, loss sebesar $0.344 \%$, recall sebesar $86.96 \%$, precision sebesar $94,5 \%$, dan $f$ measure sebesar $90.5 \%$. Nilai epoch yang digunakan dalam model yang dibangun adalah 100 , dan menggunakan 3000 dataset yang dibagi menjadi 2700 data training dan 300 data testing. Motif batik yang diklasifikasikan berjumlah 15 motif batik, yaitu motif Banji, Buketan, Ceplok, Encim, Kawung, Lung-lungan, Madura, Mega Mendung, Parang Rusak, Parang, Sekar Jagad, Truntum, Kipas, Semen, dan Fauna.

Model CNN yang dibangun menggunakan fungsi binary cross entropy untuk mengurangi data loss. Pada model ini, digunakan pula fungsi sigmoid sebagai activator, karena output yang dihasilkan model tidak bersifat mutual eksklusif dan masing-masing citra dapat terdiri dari lebih dari satu label. Klasifikasi multi-label sendiri merupakan sebuah permasalahan yang unik karena sangat memungkinkan terjadinya kasus overfitting pada dataset. Sehingga peningkatan nilai akurasi dapat dilakukan dengan menambahkan dataset motif batik multi-label untuk menghindari ketidakseimbangan data yang mampu mengakibatkan overfitting. 


\section{UCAPAN TERIMA KASIH}

Ucapan terima kasih kepada pihak DIKTI sebagai pihak pemberi dana penelitian serta kepada LPPM UISI, UMKM Batik Desa Sendangagung Lamongan, UMKM Batik Desa Manukan Bojonegoro, serta pihak-pihak terkait yang telah membantu terlaksananya penelitian ini.

\section{DAFTAR PUSTAKA}

[1] A. S. Hamidin, Batik Warisan Budaya Asli Indonesia. Yogyakarta: NARASI, 2010.

[2] J. Achjadi, The Glory of Batik: The Danar Hadi Collection, 1st ed. Solo, Central Java: PT. BATIK DANAR HADI, 2011.

[3] H. S. Doellah, Batik: the impact of time and environment. Solo: Damar Hadi, 2002.

[4] M. Ediwati, Motif Batik Tulis Kreasi Baru Produksi Batik Merak Manis di Surakarta (Sebuah Tinjauan Estetika). Surakarta: Universitas Sebelas Maret, 2007.

[5] E. Kustiyah; Iskandar, "Batik sebagai Identitas Kultural Bangsa Indonesia di Era Globalisasi," GEMA, vol. 52, pp. 2456-2472, 2017.

[6] F. K. S. Sidhi, T. A. P., Dwiandiyanta, B. Y., Dewi, "Batik Motifs Detection Using Pattern Recognition Method," J. Buana Inform., vol. 11, no. 1, pp. 55-62, 2020.

[7] M. N. Fuad; Suciati, "Klasifikasi Multilabel Motif Citra Batik Menggunakan Boosted Random Ferns," JUTI J. Ilm. Teknol. Inf., vol. 16, no. 1, pp. 79-89, 2018.

[8] A. H. Rangkuti, "Klasifikasi Motif Batik Berbasis Kemiripan Ciri dengan Wavelet Transform dan Fuzzy Neural Network," ComTech Comput. Math. Eng. Appl., vol. 5, no. 1, pp. 361-372, 2014.

[9] N. A. Haryono; Hapsari; Angesti and Felixiana, "Penggunaan Momen Invariant, Eccentricity, dan Compactness untuk Klasifikasi Motif Batik dengan K-Nearest Neighbour," J. Inform., vol. 11, no. 2, pp. 107-115, 2015.

[10] A. A. Kasim; Wardoyo; Harjoko, "Batik Classification with Artificial Neural Network Based on Texture-Shape Feature of Main Ornament," I.J. Intell. Syst. Appl., vol. 6, pp. 56-65, 2017.

[11] G. Tsoumakas; Katakis, "Multi-Label Classification: An Overview," Int. J. Data Warehous. Min., vol. 3, no. 3, pp. 1-13, 2009.

[12] W. Bi; Kwok, "Efficient Multi-label Classification with Many Labels," 2013.

[13] K. S. A. K. Yohannes, "Deteksi Penyakit Malaria Menggunakan Convolutional Neural Network Berbasis Saliency," JUITA J. Inform., vol. 8, no. 1, pp. 37-44, 2020.

[14] I. W. S. Eka Putra; A. Y. Wijaya and R. Soelaiman, "Klasifikasi Citra Menggunakan Convolutional Neural Network (Cnn) pada Caltech 101," J. Tek. ITS, vol. 5, no. 1, pp. 6569, 2016.

[15] A. Rohim; Sari, Y. A.; Tibyani, "Convolution Neural Network (CNN) Untuk Pengklasifikasian Citra Makanan Tradisional," JPTIIK (Jurnal Pengemb. Teknol. Inf. dan Ilmu Komputer), vol. 3, no. 7, pp. 7037-7042, 2019.

[16] E. N. Arrofiqoh; Harintaka, "Implementasi Metode Convolutional Neural Network untuk Klasifikasi Tanaman pada Citra Resolusi Tinggi," GEOMATIKA, vol. 24, no. 2, pp. 6168, 2018.

[17] S. F. Alamsyah, "Implementasi Deep Learning untuk Klasifikasi Tanaman Toga Berdasarkan Ciri Daun Berbasis Android," Ubiquitous Comput. its Appl. J., vol. 2, no. 2, pp. 113-122, 2019.

[18] S. A. Shahriyar; Alam, K. M. R. ; Roy, S. S. ; Morimoto, Y., "An Approach for Multi Label Image Classification Using Single Label Convolutional Neural Network," 2018.

[19] C. K. Dewa; Fadhilah, A.L.; Afiahayati, A., "Convolutional Neural Networks for Handwritten Javanese Character Recognition," IJCCS (Indonesian J. Comput. Cybern. Syst., vol. 12, no. 1, pp. 83-94, 2018.

[20] S. C. A. Pradhana; Wisesty, U. N.; Sthevanie, F., "Pengenalan Aksara Jawa dengan Menggunakan Algoritma Convolutional Neural Network," 2020. 
[21] N. H. Harani; Prianto, C. ; Hasanah, M., "Deteksi Objek Dan Pengenalan Karakter Plat Nomor Kendaraan Indonesia Menggunakan Metode Convolutional Neural Network (CNN) Berbasis Python," J. Tek. Inform., vol. 11, no. 3, pp. 47-53, 2019.

[22] B. Bhushan; Singh S.; Singla, R., "License Plate Recognition System using Neural Networks and Multi-thresholding Technique," Appl. Int. J. Comput., vol. 84, no. 5, pp. 45-50, 2013.

[23] D. Avianto, "Pengenalan Pola Karakter Plat Nomor Kendaraan Menggunakan Algoritma Momentum Backpropagation Neural Network," JIFO J. Inform., vol. 10, no. 1, pp. 1199 1209, 2016.

[24] K. N. Susanto; Gunadi, K. ; Setyanti, E., "Pengenalan Karakter pada Plat Nomor Indonesia dengan Tilt Correction dan Metode Faster R-CNN," J. INFRA, vol. 7, no. 1, 2019.

[25] M. S. Sorower, "A Literature Survey on Algorithms for Multi-label Learning," 2010.

[26] G. Tsoumakas; Katakis, I. ; Vlahavas, I., Mining Multi-label Data," in Data Mining and Knowledge Discovery Handbook. Boston, MA: Springer, 2009.

[27] S. Godbole; Sarawangi S., "Discriminative Methods for Multi-labeled Classification," in Pacific-Asia Conference on Knowledge Discovery and Data Mining," 2004.

[28] G. Lemaitre; Nogueira, F. ; Aridas, C. K., "Imbalanced-learn: A Python Toolbox to Tackle the Curse of Imbalanced Datasets in Machine Learning," J. Mach. Learn. Res., vol. 18, pp. 1-5, 2017.

[29] M. A. Tahir; Kittler, J. ; Mikolajczyk, K. ; Yan, F., "Improving Multilabel Classification Performance by Using Ensemble of Multi-label Classifiers," 2010. 